\title{
The Study of Anaerobic Co-Digestion of Non-Uniform Multiple Feed Stock Availability and Composition in Nigeria
}

\author{
E.K. Orhorhoro, P.O. Ebunilo, R.I. Tamuno and I.A Essienubong
}

\begin{abstract}
This paper reports the research work carried out on the study of anaerobic co-digestion of non-uniform multiple feed stock availability and composition in Nigeria. Organic municipal solid wastes comprises of the composition of corn cobs, potato peels, pineapple peels, rice waste, yam peels, cassava peels, orange peels, garri leftover and banana peels, was digested separately and the same time co-digested with wastewater collected from septic tanks, abattoir, and cold room in Benin City, Nigeria. The results obtained shows that the codigestion of organic municipal solid wastes and wastewater had better average biogas yields $(0.625)$, shorter retention period of 29 days, frequent number of evacuation and average rate of biogas yield of 0.0217 when compared to anaerobic digestion of organic municipal solid wastes only with an average biogas yield of 0.4025 , longer retention period of 38 days and average rate of biogas yield of 0.0106 . Therefore, anaerobic co-digestion of organic municipal solid wastes and wastewater enhances better biogas yields.
\end{abstract}

Index Terms - Organic municipal solid wastes, wastewater, biogas yields, Benin City, Nigeria

\section{INTRODUCTION}

Nigeria is the most populated country in Africa with an estimated population of 170,123,749 and a reported annual growth rate of $2.55 \%$ [1]. Biomass feed stocks can be obtained mainly from two principal different categories viz conventional agricultural products such as sugar or starchrich crops, and oilseeds; and lignocellulosic products and residues [2]. In Nigeria, agricultural land covers approximately $74,500,000$ ha of the total land area of $91,077,000$ ha for the country and about $41.2 \%$ of the agricultural land is arable land, $11.3 \%$ forest area and 3.3\% permanently cropped area [3]. About 50\% of Nigerian population is involved in agricultural production with more than $70 \%$ of the farming population practicing subsistence agricultural farming. An estimate of $48 \%$ of the country's

\section{Manuscript published July 31, 2016.}

E.K. Orhorhoro is with Cemek Machinery Company, Technology Incubation Centre, Federal Ministry of Science \& Technology. Benin City, Edo State, Nigeria (e-mail: kelecom @yahoo.com)

P.O. Ebunilo is with Department of Mechanical Engineering, Faculty of Engineering, University of Benin. Benin City, Edo State, Nigeria. (e-mail: Patrick.ebunilo@uniben.edu)

R.I. Tamuno is with Power Equipment and Electrical Machinery Development Institute, National Agency for Science and Engineering Infrastructure (NASENI), Federal Ministry of Science and Technology, Okene, Kogi State, Nigeria (e-mail:favour_rogers2006@yahoo.com)

I.A Essienubong is with Department of Mechanical Engineering, Faculty of Engineering, Universty of Benin. Benin City, Edo State, Nigeria (e-mail: ikpeaniekan@gmail.com) population lives in the rural area with more than

$70 \%$ of the country's population living below poverty level, and the means of energy is through wood fuel and charcoal which has contributed immensely to desertification, deforestation and erosion in the country $[1,4]$.

Anaerobic digestion (AD) process has become an increasingly important industrial process. The production of biogas from $\mathrm{AD}$ process is of growing interest to many developed countries like Sweden, Germany, USA, Canadan, China, etc. and developing countries like Nigeria, Sudan, Ethiopia, Ghana and other Africa countries, as fossil-fuel resources decline [4-9]. The increasing world-wide awareness and concern about the environmental impacts of fossil fuels, nuclear power especially the danger involved in it such as the tsunami in Japan, which resulted in the meltdown of a nuclear reactor at Fukushima has made the world to shift their attention to renewable energy [10-12]. Research has shown that the area of renewable energy have proven to be a very powerful instrument and the development of highly efficient renewable energy processes and their optimization moves at an unprecedented pace across the world especially from the year 2000 to 2015 as shown in Table I[13,14]. There was an increase in the share of renewable energy in gross final energy consumption in Europe. For instance there is an increase by more than $50 \%$ between 2004 and 2010 and from $8.1 \%$ to $12.5 \%$ with renewable energy from biomass being the main contributor $[15,16]$ though developing countries like Nigeria and other Africa countries are still lagging behind [4, 17-19].

TABLE I: FINAL ENERGY CONSUMPTION OF ENERGY SOURCE GLOBALLY (in EJ)

\begin{tabular}{lccccccc}
\hline \hline Year & Total & Coal & \multicolumn{1}{c}{ Oil } & $\begin{array}{l}\text { Natural } \\
\text { gas }\end{array}$ & Nuclear & Renewable & $\begin{array}{l}\text { Renewable } \\
(\%)\end{array}$ \\
\hline 2000 & 270 & 44.4 & 115 & 55.5 & 7.64 & 47.8 & 17.7 \\
2005 & 301 & 54.9 & 125 & 60.7 & 8.23 & 52.1 & 17.3 \\
010 & 332 & 64.8 & 130 & 68.9 & 8.26 & 60.0 & 18.1 \\
2011 & 338 & 67.6 & 131 & 69.9 & 7.74 & 61.4 & 18.2 \\
2012 & 342 & 68.7 & 132 & 70.3 & 7.39 & 63.0 & 18.4 \\
\hline \hline \multicolumn{7}{c}{ Source: IEA, WBA 2015 }
\end{tabular}

Waste is defined as left over, or already used items waiting for reuse or disposal [20]. Waste water is any water that has been adversely affected in quality due to human activities. Waste water includes domestic liquid waste from residences and industries [21]. Wastes from most towns in Nigeria are often poorly managed and sometimes discharge into adjoining streams due to poor implementation of standards, thus causing environmental and public health 
hazards [22-23]. These wastes are also associated with potential transferable antimicrobial resistance patterns, and decrease in air quality leading to communicable and zoonotic diseases such as tuberculosis, cysticercosis and trichinoses [24].

Nigeria generates $6.034 \%$ of total world biomass. Nigeria biogas potential is estimated at 25.53 billion $\mathrm{m}^{3}$ per year [25]. Also, Nigeria streets and homes are dumping grounds for municipal solid wastes, wastewater etc. of which organic municipal solid wastes constitute the highest percentages of these solid municipal solid wastes dumps across various cities in Nigeria [26, 27]. Nigeria major sources of energy for heating and lighting is from fossil fuels and the high cost and unavailability has frustrated the majority of the Nigeria citizens who are in the low income group. Therefore, it became necessary to look into other sources of energy supply that are renewable and sustainable. Thus, exploitation of these wastes could provide alternative energy for the entire populace. This research work is aimed at the study of the anaerobic co-digestion of the available nonuniform multiple feed stocks such as organic municipal solid wastes and wastewater in Nigeria.

\section{MATERIALS AND METHODS}

Wastewater was collected from septic tanks, abattoir, and cold room in Benin City, Nigeria. Also, organic municipal solid wastes were collected from households and restaurants in Benin City, Nigeria. The composition of organic municipal solid wastes used comprises of corn cobs, potato peels, pineapple peels, rice wastes, yam peels, cassava peels, orange peels, garri left over and banana peels. The wastewater is sieved and then thickened to dry solids of reasonable content in order to avoid too high energy consumption for heating due to excessive water content. The carbon-nitrogen ratio, total solids (TS) and volatile solids (VS) of wastewater and organic municipal solid wastes used were determined as shown in Table II.

TABLE II: CHARACTERISTICS OF WASTEWATER AND NON-UNIFORM MULTIPLE FEED STOCKS USED

\begin{tabular}{lccc}
\hline \hline Parameter & Wastewater & $\begin{array}{l}\text { Organic } \\
\text { municipal solid } \\
\text { wastes }\end{array}$ & Inoculums \\
\hline Volatile solid (\%) & 2.95 & 19.02 & 16.03 \\
Total solid (\%) & 4.09 & 26.07 & 20.01 \\
Total Nitrogen & 4.51 & 3.21 & 2.01 \\
Total Carbon & 39.04 & 69.07 & 29.05 \\
C/N ratio & $8.66: 1$ & $21.52: 1$ & 14.45 \\
\hline \hline
\end{tabular}

A weighing balance was used to measure both $50 \mathrm{~kg}$ of organic municipal solid wastes and wastewater respectively. The collected organic municipal solid wastes were cut into pieces with knife to increase its surface area, mixed with water in ratio of 1:2 and were charged into $100 \mathrm{~L}$ each in the following order; organic municipal solid wastes and codigestion of wastewater and organic municipal solid wastes. This was made airtight for digestion to take place and the operation/process parameter was properly monitored. The digester content was stirred several times per day with the aim of mixing the substrates inside the digester for efficient biogas yields.

The rate of biogas yield, frequency of evacuation and flow rate were calculated as follow.

$$
\begin{aligned}
& R_{B Y}=\frac{B Y}{H R T} \\
& F E_{R}=\frac{N_{E}}{H R T} \\
& Q=\frac{V}{H R T}
\end{aligned}
$$

Where,

$\mathrm{BY}=$ Biogas Yield

HRT $=$ Hydraulic Retention Time

$\mathrm{N}_{\mathrm{E}}=$ Number of Evacuation

$\mathrm{R}_{\mathrm{BY}}=$ Rate of Biogas Yield

$\mathrm{FE}_{\mathrm{R}}=$ Frequency of evacuation rate

$\mathrm{Q}=$ Flow Rate

$\mathrm{V}=$ Working Volume of the Digester

The total and average biogas yield, rate of biogas production, hydraulic retention time, frequency of evacuation and cumulative frequency of evacuation was calculated as shown.

$$
\mathrm{A}=\frac{\Sigma \mathrm{X}}{\mathrm{n}}
$$

Where,

$\mathrm{A}=$ Average of each process

$\Sigma \mathrm{X}=$ Sum of each process

$\mathrm{n}=$ Number of each process

\section{RERESULTS AND DISCUSSION}

The results obtained with anaerobic digestion of organic municipal solid wastes and co-digestion of wastewater with

\begin{tabular}{|c|c|c|c|c|c|}
\hline \multirow{2}{*}{$\mathrm{S} / \mathrm{N}$} & \multicolumn{5}{|c|}{ Organic Municipal Solid Wastes } \\
\hline & BY & HRT & $\mathrm{R}_{\mathrm{BY}}$ & $\mathrm{NE}$ & $\mathrm{FE}_{\mathrm{R}}$ \\
\hline 1 & 0.12 & 38 & 0.0032 & 12 & 0.3158 \\
\hline 2 & 0.19 & 38 & 0.0050 & 4 & 0.1053 \\
\hline 3 & 0.40 & 38 & 0.0105 & 4 & 0.1053 \\
\hline 4 & 0.35 & 38 & 0.0092 & 3 & 0.0789 \\
\hline 5 & 0.89 & 38 & 0.0234 & 3 & 0.0789 \\
\hline 6 & 0.69 & 38 & 0.0182 & 4 & 0.1053 \\
\hline 7 & 0.38 & 38 & 0.0100 & 4 & 0.1053 \\
\hline 8 & 0.20 & 38 & 0.0053 & 4 & 0.1053 \\
\hline$\Sigma \mathrm{n}=8$ & $\begin{array}{l}\Sigma \mathrm{BY}= \\
3.22\end{array}$ & $\begin{array}{l}\Sigma \text { HRT } \\
=304\end{array}$ & $\begin{array}{l}\Sigma \mathrm{R}_{\mathrm{BY}}= \\
0.0848\end{array}$ & $\begin{array}{l}\Sigma \mathrm{N}= \\
28\end{array}$ & $\begin{array}{l}\Sigma \mathrm{FE}_{\mathrm{R}}= \\
1.0001\end{array}$ \\
\hline$A=1$ & $\mathrm{~A}=0.4025$ & $A=38$ & $A=0.0106$ & $A=3.5$ & $\begin{array}{l}A= \\
0.1250\end{array}$ \\
\hline
\end{tabular}
organic municipal solid wastes is shown in Table III- IV.

TABLE III: RESULTS OF ANAEROBIC DIGESTION OF ORGANIC MUNICIPAL SOLID WASTES 
TABLE IV: SOLID WASTES AND WASTEWATER LID WASTES

\begin{tabular}{llllll}
\hline \hline \multirow{2}{*}{$\mathrm{S} / \mathrm{N}$} & \multicolumn{5}{c}{ Organic Municipal Solid Wastes } \\
\cline { 2 - 6 } 1 & $\mathrm{BY}$ & $\mathrm{HRT}$ & $\mathrm{R}_{\mathrm{BY}}$ & $\mathrm{NE}$ & $\mathrm{FE}_{\mathrm{R}}$ \\
2 & 0.30 & 29 & 0.0103 & 8 & 0.2759 \\
3 & 0.35 & 29 & 0.0121 & 3 & 0.1034 \\
4 & 0.49 & 29 & 0.0169 & 3 & 0.1034 \\
5 & 0.85 & 29 & 0.0293 & 2 & 0.0690 \\
6 & 1.05 & 29 & 0.0362 & 1 & 0.0345 \\
7 & 0.96 & 29 & 0.0331 & 1 & 0.0345 \\
8 & 1.00 & 29 & 0.0345 & 2 & 0.0690 \\
9 & 0.91 & 29 & 0.0314 & 2 & 0.0690 \\
10 & 0.19 & 29 & 0.0066 & 3 & 0.1034 \\
$\Sigma \mathrm{n}=10$ & 0.18 & 29 & 0.0062 & 4 & 0.1379 \\
$\mathrm{~A}=1$ & $\mathrm{~A}=0.625$ & $\mathrm{~A}=29$ & $\mathrm{~A}=0.02$ & $\mathrm{~A}=2$. & $\mathrm{A}=0.100$ \\
& & & 17 & 9 & \\
\hline \hline
\end{tabular}

From Table III- IV the anaerobic co-digestion of organic municipal solid wastes and wastewater had better average biogas yields $(0.625)$ when compared to anaerobic digestion of organic municipal solid wastes only with an average biogas yield of 0.4025 . This means that the wastewater enhanced biogas yields. Also, because of better biogas build up in the co-digestion of organic municipal solid wastes with waste water, the number and the frequency of evacuation of biogas yields was better in comparison to digestion of organic municipal solid wastes (Fig.1)

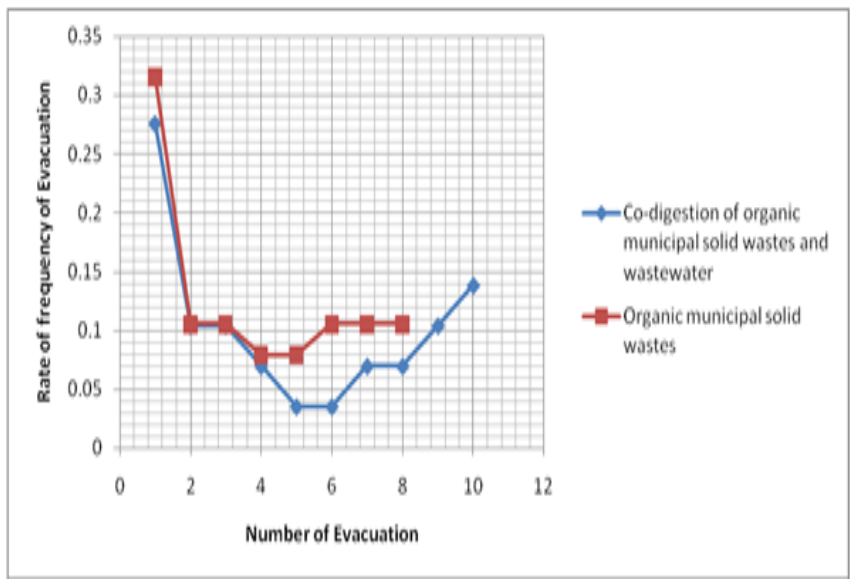

Fig. 1. Plot of Rate of Frequency of Evacuation

The rate of biogas yields is shown in Fig. 2, with the codigestion of organic municipal solid wastes and wastewater having the best rate of biogas yields. Thus, the anaerobic digestion stages (i.e. hydrolysis, acidogenesis, acetogenesis and methanogenesis) in the co-digestion of organic municipal organic municipal solid wastes and wastewater were completed in a shorter time. The faster the digestion of the substrates, the shorter the hydraulic retention time hence twenty nine (29) days for the co-digestion of organic municipal solid wastes and wastewater and thirty eight (38) days for the digestion of organic municipal solid wastes only.

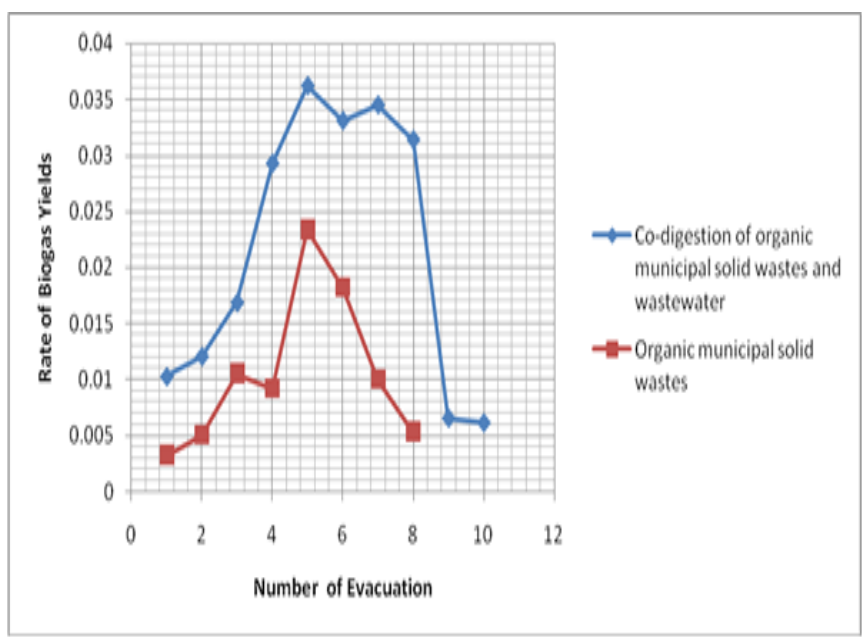

Fig.2. Plot of Rate of Biogas Yields

Fig.3 shows the plot of biogas yields, with the codigestion of organic municipal solid wastes and wastewater with better biogas yields and the optimum biogas yields (1.05) obtained on the fifth evacuation within a yielding period of one (1) day.

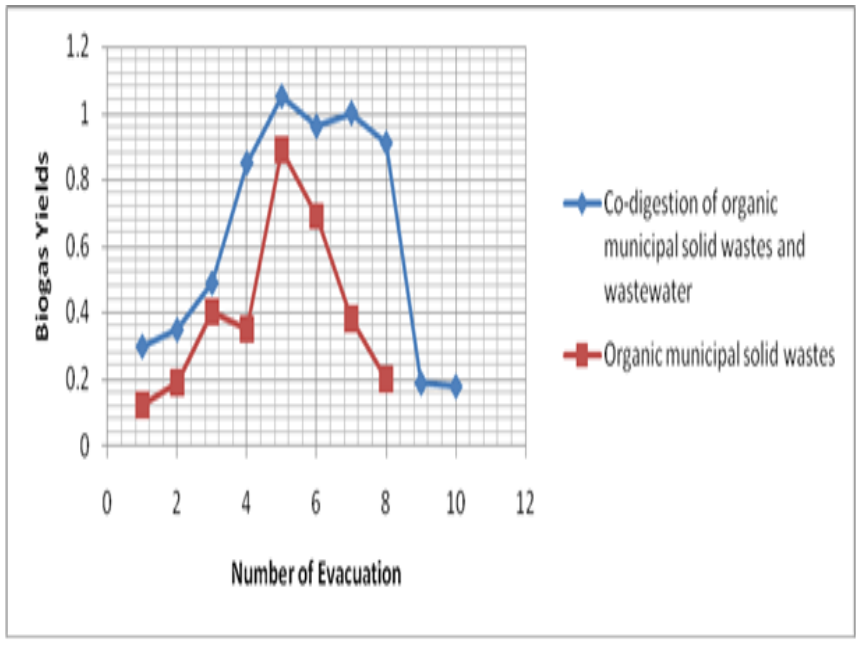

Fig. 3. Plot of Biogas Yeilds

\section{CONCLUSION}

In this research work which has to do with the study of anaerobic co-digestion of non-uniform multiple feed stock availability and composition in Nigeria, improvement of biogas yields was achieved with the co-digestion of organic municipal solid wastes with wastewater. The process is cost effectiveness and is a means of reducing organic municipal solid wastes and wastewater in a recycling manner. Hence, for optimum biogas yields, co-digestion of substrates with wastewater is recommended.

\section{REFERENCES}

[1] CIA, "The World factbook", Nigeria http://www.cia.gov/library/publications/the world factbook/index.html. Accessed 24th August 2012

[2] P. Girard, A. Fallot,"Review of existing and emerging technologies for the production of biofuels in developing countries", Energy for Sustainable Development, Vol. 10, No. 2, pp.92-108, October 2006

[3] E.J. Simonyan, and O. Fasina," Biomass resources and bioenergy potentials in Nigeria", Africa Journal of Agricultural research, Vol. 8(40), pp. 4975-4989, 17 October, 2013

[4] A.S. Sambo, "Renewable energy electricity in Nigeria, The way forward", Paper presented at the Renewable Electricity Policy 
Conference held at Shehu Musa Yarádua Centre, Abuja. pp.11-12, December, 2006

[5] Energy Commission of Nigeria."Communiqué of National workshop on sustainable Jatropha for energy development. 6th -7th May, Mambayya house, Kano", www.energy.gov.ng. Accessed on 3rd January 2013

[6] A.H. Igoni, M.J. Ayotamuno, C.L. Eze, S.O.T. Ogaji, and S.D Probert, "Designs of anaerobic digesters for producing biogas from municipal solid-waste". Applied Energy vol.85, pp. 430-438, October 2008

[7] E. Bruni, A.P. Jensen, E.S.Pedersen, and I. Angelidaki, "Anaerobic digestion of maize focusing on variety, harvest time and pretreatment", Appl. Energy, vol.87, Iss.7, pp.2212- 2217, July 2010

[8] P.O. Ebunilo, S.A. Aliu, and E.K. Orhorhoro, "Performance Study of a Biogas Pilot Plant using Domestic Wastes from Benin Metropolis". International Journal of Thermal \& Environmental Engineering volume 10, No 2, 2015

[9] E.K. Orhorhoro, O.W. Orhorhoro and P.O. Ebunilo, "Analysis of the effect of carbon/nitrogen $(\mathrm{C} / \mathrm{N})$ ratio on the performance of biogas yields for non-uniform multiple feed stock availability and composition in Nigeria", International Journal of Innovative science \& Technology, Vol. 3 Issue 5, May 2016

[10] J.K.F. Akinbami, M.O. Ilori, T.O. Oyebisi, I.O. Akinwumi, and O. Adeoti, "Biogas energy use in Nigeria: current statue, future projects Projects and policy implication", Renewable and sustainable Energy Reviews, Volume 5, Issue 1, March 2001, pp. 97-112

[11] E.N.C. Okafor, and J.Uzuegbu, "Challenges to Development of Renewable Energy for Electric Power Sector in Nigeria". International Journal of Academic Research, Vol. 2, No. 2, 2010

[12] Nuclear and Industrial Safety Agency, "Off the Pacific coast of Tohoku Pacific Earthquake and the seismic damage to the NPPs", March 2011

[13] A.V. Da Rosa, Fundamentals of renewable energy processes. 3rd ed. Oxford: Academic Press, 2013

[14] IEA BIOENERGY TASK 37,"REVA Certified Wastewater Treatment Plants in Sweden for Improved Quality of Recycled Digestate Nutrients, Case Study", Available from:http://www.ieabiogas.net/case-studies.html, April 2015

[15] Eurostat, Share of renewable energy in gross final energy consumption (\%), Available from: http://epp.eurostat.ec.europa eu/tgm/table.do?tab=table \&plugin $=1 \&$ language $=$ en $\quad \& \quad \mathrm{p} \quad$ code $=$ t2020_c31, Accessed 25 February 2013

[16] Eurostat, Energy statistics: Supply, transformation, consumption - all products annual data. Energy statistics: Supply, transformation, consumption - renewables and wastes (total, solar heat, biomass, geothermal, wastes) - Annual data. Energy statistics: Supply, transformation, consumption - renewables (hydro, wind, photovoltaic)-annual data Available from: http:// epp.eurostat.ec. europa.eu/portal/page/portal/energy/data/database, 2013

[17] Federal Government of Nigeria, "Renewable Electricity Policy Guidelines, Federal Ministry of Power and Steel". P. 37, 2006

[18] S.O. Akande, F.B. Olorunfemi, "Research and development potentials in Biofuels production in Nigeria". African Res. Re 3(3):3445, 2009

[19] J.K. Akinbami, "Renewable Energy Resources and Technologies in Nigeria: Present Situation, Future Prospects and Policy Framework". Mitigation and Adaptation Strategies for Global Change 6: pp155188. Kluwer Academic Publishers. Netherlands, 2011

[20] T.O.K. Audu, E.O. Aluyor, "Potential of Bioenergy and Biofuels technology development in Nigeria". Petroleum Technology Development Journal,(ISSN 1595-9104, Vol.1, pp. 1-7,January 2012

[21] F. Burton and H Stense, "Wastewater Engineering, Treatment and Reuse, $4^{\text {th }}$ edition", mcgraw hill, new York, USA, 2003

[22] O. Osibanjo and G.U. Adie"Impact of effluent from Bodija abbatoir on the physiochemical parameters of Oshunkaye stream in Ibadan City, Nigeria", Africa Journals of Biotechnology, 6(15), pp. 18061811,2007

[23] B.A. Adelekan, A.I. Bamgboye, "Comparison of Biogas Productivity of Cassava Peels Mixed in Selected Raios with Major Livestocks

Waste Types", Africa Journal of Agricultural Research, Vol. 4(7), pp.571-577, 2009

[24] J.A. Nwanta, J.I. Onunkwo, V.E. Ezenduka, P. Phil-Eze and S.C. Egege, "Abbattoir operations and waste management in Nigeria: A review of challenges and prospects", Sokoto Journal of Veterinatry Sciences, 7(2), pp. 61-67, 2008.

[25] C.N. Chima, N.O. Jude, C.O. Justina and S.A. Ekpewerechi S.A. (2013). "Biogas potential of organic waste in Nigeria". Journal of Urban and Environmental Engineering, Vol.7, No. 1, pp. 110- 116, 2013

[26] M. Eisa, and C. Visvanathan, Municipal solid waste management in Asia and Africa. A comparative analysis. Cleaner production and Environmental Management Branch, United Nations Industrial Development Organization. Vienna, Austria, 2002

[27] D.I. Igbinomwanhia, E.N. Ohwovoriole, "A study of the constraints to Residential Solid Wastes Management Benin Metropolis, Nigeria". Journal of Emerging Trends in Engineering and Applied Science (JETEAS) 3(1): 103-107, 2012 (ISSN: 2141-7016)
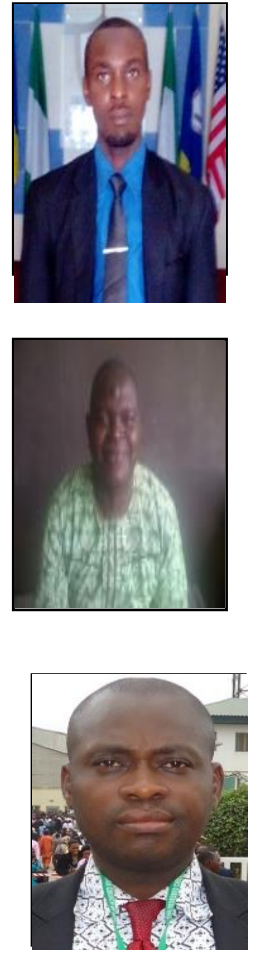

Nigeria.

favour_rogers2006@yahoo.com

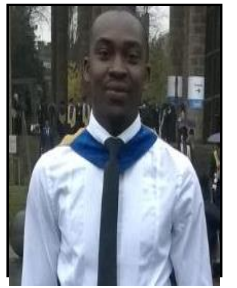

Essienubong Aniekan Ikpe B. Eng. Mechanical Engineering 2010- University of Uyo, Akwa Ibom State. Nigeria; M.Sc (2014)Coventry University, United Kingdom $\mathrm{PhD}$ student, Department of Mechanical Engineering, University of Benin, Benin City, Edo State, Nigeria. ikpeaniekan@gmail.com 